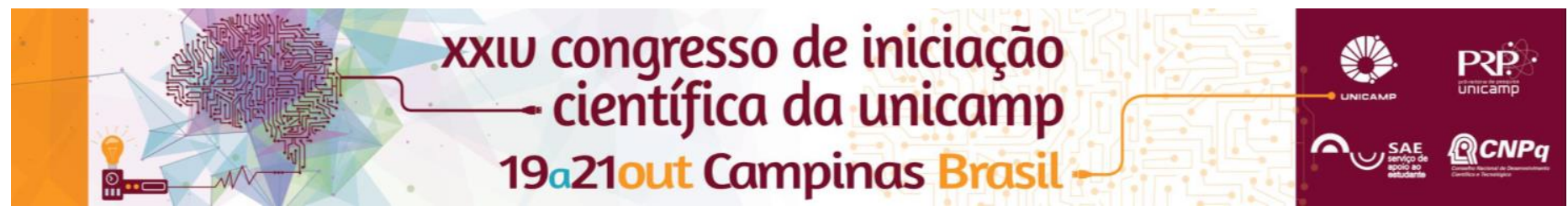

\title{
"Mão aos alto! Seu corpo é uma ameaça": Cenários sensoriais e preservação da cultura material na legislação do patrimônio arqueológico brasileiro
}

\author{
Clarita Maria de Godoy Ferro*, Prof ${ }^{\mathrm{a}}$ Drª Aline Vieira de Carvalho. IFCH/UNICAMP
}

\section{Resumo}

Com o objetivo de compreender a impossibilidade de práticas multisensoriais na maior parte dos museus brasileiros, esta pesquisa mapeia os impedimentos jurídicos atuantes sobre os diversos modos de fruição sensorial do patrimônio arqueológico brasileiro ao longo do século XX.

\section{Palavras-chave: \\ Legislação Arqueológica Brasil, Preservação do Patrimônio, Arqueologia Sensorial.}

\section{Introdução}

"Proibido tocar!". Quando visitamos um museu de arqueologia esse imperativo pode ser bem comum. Por toda a parte encontramos vitrines e, até mesmo, câmeras cercando os objetos. Um dos incômodos que essas fronteiras tentam evitar é a aproximação de nossos corpos e sentidos daquelas peças. Mas por que nossa aproximação não é permitida? Por que nosso toque, nossa experiência multissensorial ao patrimônio arqueológico é considerada uma ameaça à sua preservação? São essas perguntas que conduzem esta pesquisa, a qual pretende mapear os impedimentos jurídicos atuantes sobre os diversos modos de fruição sensorial do patrimônio arqueológico brasileiro ao longo do século XX.

\section{Resultados e Discussão}

A fim de contemplarmos o objetivo da pesquisa, foi selecionada documentação composta pelo Decreto-le no 25 de 27 de novembro de 1937 (DL 25/27); pela Lei no 3.924 de 26 de julho de 1961 (L 3.924/61); pelos Artigos 215 e 216 da Constituição Federal de 1988 e pela Portaria № 07 de 01 de dezembro de 1988.

O Decreto-lei no 25 de 27 de novembro de 1937 foi publicado no governo Vargas. Sua principal disposição foi a criação do Serviço do Patrimônio Histórico e Artístico Nacional (SPHAN), responsável pela instituição da prática do tombamento, amplamente realizada na cidade mineira de Ouro Preto, por exemplo. Todavia, por imprecisões jurídicas, o DL25/27criava impasses à própria escavação arqueológica, que poderia ser interpretada como forma de destruição do patrimônio.

Sendo assim, sob o governo de Jânio Quadros, foi publicada a Lei 3.924/1961, responsável por estabelecer regime exclusivo de preservação para os bens arqueológicos, não estando mais vinculado ao tombamento. Agora, a proteção desses bens se resumiria à sua inscrição em um cadastro de bens arqueológicos do Brasil; uma espécie de registro de todos os sítios existentes no território nacional.

Com o estabelecimento de uma nova constituição brasileira em 1988, a cultura, de forma inédita, passou a ter uma seção exclusiva, composta pelos artigos 215 e 216. O primeiro propõe maior inclusão ao assegurar a proteção de manifestações culturais populares, indígenas e afro-brasileiras. Já o seguinte atribui atenção especial para o caso do patrimônio cultural brasileiro, que passa a ser entendido como "(...) os bens de natureza material e imaterial, tomados individualmente ou em conjunto, portadores de referência à identidade, à ação, à memória dos diferentes grupos formadores da sociedade brasileira (...)".

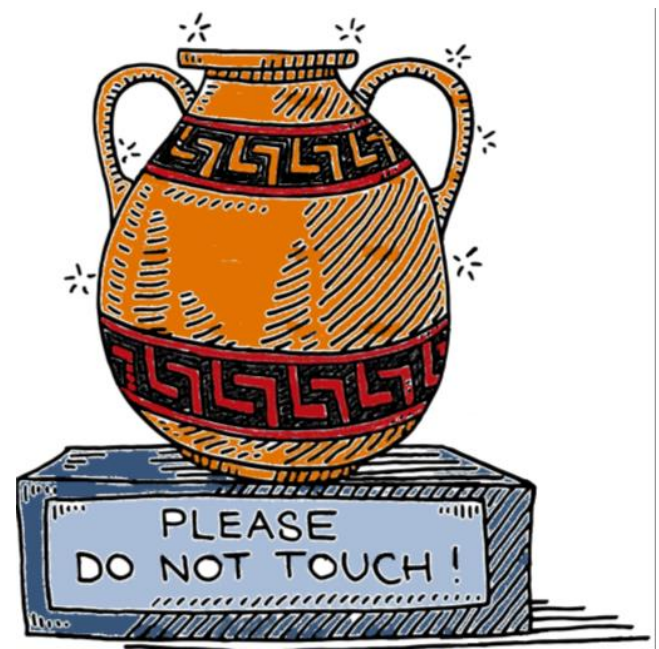

Figura 1. "Por favor, não toque!"

\section{Conclusões}

Após a análise das legislações, pudemos evidenciar o uso de conceitos referentes ao patrimônio e à preservação. O DL $25 / 37$, elenca o tombamento como principal medida preservacionista, o que significa o impedimento de atos como demolição.

Já na lei no 3.924/1961, a atenção ao bem arqueológico é redobrada, dando atenção à proteção dos objetos relacionados à cultura paleo-ameríndia no Brasil, seguindo a máxima "conhecer para preservar".

Por sua vez, os artigos 215 e 216 da Constituição de 1988 trazem uma concepção de patrimônio mais ampla. Agora, bens de natureza imaterial e também aqueles que representam a diversidade dos grupos formadores da sociedade brasileira puderam ser incluídos.

A partir dos resultados, concluímos que não há menção direta aos agentes de risco ao patrimônio, muito menos prescrições acabadas sobre o melhor meio de salvaguarda do patrimônio arqueológico.

${ }^{1}$ CLASSEN, C. Museum manners: the sensory life of the early museum. In Journal of Social History, 2007, pp. $895-914$. 